\title{
Metabolic Properties of IgG Subclasses in Man
}

\author{
Andreas Morell, William D. Terry, and Thomas A. Waldmann \\ From the Immunology Branch, Metabolism Branch, National Cancer Institute, \\ National Institutes of Health, Bethesda, Maryland 20014
}

A B S T A C T Metabolic properties of the four subclasses of human IgG were investigated by performing 47 turnover studies in individuals with normal IgG serum concentrations, as well as in patients with an increased level of one of the subclasses. Studies in 12 subjects with normal IgG serum concentration showed that the average biologic half-life of $G_{1}, G_{2}$, and $G_{4}$ was 21 days, while that of $\mathrm{G}_{3}$ was only 7.1 days. Fractional catabolic rates of $\mathrm{G}_{1}, \mathrm{G}_{2}$, and $\mathrm{G}_{4}$ were 6.9 to $8 \%$ of the intravascular pool per day. $\mathrm{G}_{3}$, however, had a higher fractional catabolic rate, amounting to $16.8 \%$ of the intravascular pool per day. Distribution of the subclasses was such that the intravascular compartment contained 51$54 \%$ of the total body pools of $\mathrm{G}_{1}, \mathrm{G}_{2}$, and $\mathrm{G}_{4}$, but $64 \%$ of the total body pool of $\mathrm{G}_{3}$.

The short survival and high fractional catabolic rate of $\mathrm{G}_{3}$ is an inherent property of these molecules, and is not due to denaturation during isolation and radiolabeling. This was demonstrated by studies of a patient with a serum $\mathrm{G}_{3}$-myeloma protein. The survival of her own protein, separately labeled either in vivo with guanidoarginine $-{ }^{14} \mathrm{C}$ or in vitro with ${ }^{125} \mathrm{I}$, was determined in the patient. Survivals of the in vivo and in vitro labeled proteins were identical.

$\mathrm{G}_{1}$ and $\mathrm{G}_{3}$ serum concentrations and synthetic rates were determined. The mean serum concentration of $\mathrm{G}_{1}$ was $6.8 \mathrm{mg} / \mathrm{ml}$ and that of $\mathrm{G}_{3}$ was $0.7 \mathrm{mg} / \mathrm{ml}$, while their synthetic rates were 25.4 and $3.4 \mathrm{mg} / \mathrm{kg}$ per day respectively. The low serum concentration of $\mathrm{IgG}_{3}$ thus results from a combination of high catabolic and low synthetic rates.

Studies in 10 patients with multiple myeloma showed that an elevated serum concentration of any IgG subclass was associated with shortened biologic half-life and increased fractional catabolic rate of all subclasses. The implications of this concentration-catabolism relationship are discussed. The serum concentration of nonmyeloma IgG was usually low in myeloma patients and

Andreas Morell is a Fellow of the Swiss Center for - Clinical Tumor Research, Bern, Switzerland.

Received for publication 19 September 1969. the synthesis of nonmyeloma IgG was somewhat decreased, suggesting that low serum concentrations of nonmyeloma IgG result from decreased synthesis, as well as from an increased fractional catabolic rate.

\section{INTRODUCTION}

Many metabolic features of human IgG have been demonstrated by turnover studies using $\operatorname{IgG}$ isolated from normal human serum. IgG, however, is heterogeneous and consists of four distinct species of molecules designated $\mathrm{IgG}_{1}, \mathrm{G}_{2}, \mathrm{G}_{3}$, and $\mathrm{G}_{4}$. All four of these subclasses are present in normal human serum, and in a normal indivdual the relative concentrations are: $\mathrm{G}_{1}$, $65 \% ; \mathrm{G}_{2}, 23 \% ; \mathrm{G}_{3}, 8 \%$; and $\mathrm{G}_{4}, 4 \%$ (1). Previous studies have, therefore, really determined the metabolic properties of a heterogeneous group of proteins.

Molecules of the four subclasses differ from one another in the antigenic and chemical structure of the carboxy terminal three-quarters of their gamma chains. One portion of this region, the Fc-fragment, determines a number of the biologic, nonantibody activities of $\mathrm{IgG}$, including the rate of catabolism $(2,3)$. The subclasses differ in their Fc-fragments and therefore might also be expected to differ in metabolic properties. Investigation of characteristics of indivdual subclasses cannot be performed using normal serum IgG, because the molecules in normal serum have very similar charge and size and cannot be completely separated from one another. It is necessary, instead, to use G-myeloma proteins (G-MP) each of which serves as a representative of a subclass and can be obtained free of other subclasses.

Spiegelberg and coworkers $(4,5)$ have investigated one aspect of the metabolism of human IgG subclasses by comparing the biologic half-life of a number of isolated G-MP's in man and other species. They found that the average biologic half-life of $G_{1}, G_{2}$, and $G_{4}$ were similar, but that the half-life of $\mathrm{G}_{3}$ was shorter than the others.

The purpose of the present study was to gather more information about the metabolism of the $\operatorname{IgG}$ subclasses 
TABLE I

Clinical and Turnover

\begin{tabular}{|c|c|c|c|c|c|c|c|c|c|c|c|c|c|}
\hline \multirow[b]{2}{*}{ Initials } & \multirow[b]{2}{*}{ Sex } & \multirow[b]{2}{*}{ Age } & \multirow[b]{2}{*}{ Weight } & \multirow{2}{*}{$\begin{array}{l}\text { Serum- } \\
\text { IgG }\end{array}$} & \multirow[b]{2}{*}{ Diagnosis } & \multicolumn{4}{|c|}{ Survival $t_{\mathbf{z}}$} & \multicolumn{4}{|c|}{$\begin{array}{l}\text { Fraction of intravascular pool } \\
\text { catabolized per day }\end{array}$} \\
\hline & & & & & & $\mathrm{G}_{1}$ & $\mathrm{G}_{2}$ & $\mathrm{G}_{3}$ & $\mathrm{G}_{4}$ & $\mathrm{G}_{1}$ & $\mathrm{G}_{2}$ & $\mathrm{G}_{3}$ & $\mathrm{G}_{4}$ \\
\hline & & $y r$ & kg & $m g / m l$ & \multicolumn{9}{|c|}{ days } \\
\hline M. G. & $\mathbf{F}$ & 62 & 52.3 & 9.0 & Malignant lymphoma & & 23 & 8.0 & & & 0.068 & 0.175 & \\
\hline A. $W$. & $\mathbf{F}$ & 72 & 72.7 & 15.0 & Mycosis fungoides & & 18 & 6.4 & & & 0.067 & 0.167 & \\
\hline W. A. B. & $\mathbf{M}$ & 65 & 73.4 & 10.4 & $\begin{array}{l}\text { Metastatic carcinoma of } \\
\text { the colon }\end{array}$ & & 21 & 6.3 & & & 0.066 & 0.159 & \\
\hline H. E. H. & $\mathbf{M}$ & 61 & 64.7 & 10.0 & $\begin{array}{l}\text { Squamous cell carcinoma of } \\
\text { the oral cavity }\end{array}$ & & 19 & 7.7 & & & 0.073 & 0.162 & \\
\hline J. H. & $\mathbf{F}$ & 25 & 56.8 & 8.6 & Metastatic choriocarcinoma & & & 7.7 & & & & 0.172 & \\
\hline P. E. W. & $\mathbf{M}$ & 40 & 71.4 & 8.1 & Metastatic melanoma & & & 6.4 & & & & 0.174 & \\
\hline J. J. & $\mathbf{M}$ & 20 & 64.5 & 12.0 & Choriocarcinoma & 18 & & & 24 & 0.082 & & & 0.058 \\
\hline C. B. & $\mathbf{F}$ & 65 & 56.0 & 8.3 & Carcinoma of the breast & 30 & & & 23 & 0.045 & & & 0.055 \\
\hline B. L. C. & $\mathbf{F}$ & 42 & 61.5 & 6.4 & Carcinoma of the breast & 16 & & & 19 & 0.092 & & & 0.073 \\
\hline E. W. & $\mathbf{F}$ & 36 & 73.0 & 8.7 & Pheochromocytoma & 26 & & & & 0.06 & & & \\
\hline M. E. H. & F & 59 & 52.5 & 13.5 & Rheumatoid arthritis & 22 & & & 20 & 0.10 & & & 0.09 \\
\hline E. L. & $\mathbf{F}$ & 50 & 59.0 & 15.0 & Sjögren's syndrome & 15 & & & 17 & 0.10 & & & 0.07 \\
\hline Mean & & & & & & 21.2 & 20.2 & 7.1 & 20.6 & 0.08 & 0.069 & 0.168 & 0.069 \\
\hline $\pm s o$ & & & . & & & \pm 5.4 & \pm 1.9 & \pm 0.7 & \pm 2.6 & \pm 0.02 & \pm 0.003 & \pm 0.006 & \pm 0.014 \\
\hline
\end{tabular}

and about the mechanisms that regulate their serum levels in man. 47 turnover studies with radiolabeled G-myeloma proteins of the different subclasses were performed in 24 individuals. The distribution between intra- and extravascular compartments, the rates of catabolism of all four subclasses, and the rates of synthesis of $\mathrm{G}_{1}$ and $\mathrm{G}_{3}$ were determined.

An attempt was made to answer the following three questions: (a) What are the metabolic characteristics of the four IgG subclasses in individuals with normal levels of IgG? (b) Is the apparently short survival of $\mathrm{G}_{3}$ due to damage sustained by this labile molecule during isolation and radioiodination? (c) What is the effect of a high serum concentration of any one of the IgG subclasses on the synthesis and survival of all four subclasses?

\section{METHODS}

Isolation and radioiodination of proteins. Five myeloma proteins (types $\mathrm{G}_{1} \lambda, \mathrm{G}_{2} \kappa, \mathrm{G}_{8} \kappa, \mathrm{G}_{3} \lambda$, and $\mathrm{G}_{4} \kappa$ ) were isolated from serum by zone electrophoresis and if necessary Sephadex G-200 gel filtration. ${ }^{1}$ Purity of isolated proteins was assessed by immunoelectrophoresis and Ouchterlony analysis. Preparations contained no serum proteins other than IgG. Proteins were labeled with ${ }^{101} \mathrm{I}$ or ${ }^{125} \mathrm{I}$ by the iodine monochloride method of McFarlane (6). All preparations had an average of less than one atom of iodine per molecule and contained less than $1 \%$ nonprecipitable radioactivity. Iodinated preparations were made $3.5 \%$ in human albumin to minimize radiation damage. Preparations were sterile filtered and tested for sterility and pyrogenic activity before use.

Measurement of immunoglobulin concentrations. Serum concentrations of $\mathrm{IgG}, \mathrm{IgG}_{1}$, and $\mathrm{IgG}_{3}$ were determined by

\footnotetext{
${ }^{1}$ Pharmacia Fine Chemicals Inc., Uppsala, Sweden.
}

a method of inhibition of immune binding (7). Monkey or rabbit antisera were absorbed so as to be specific for the heavy chains of $\mathrm{IgG}, \mathrm{G}_{1}$, or $\mathrm{G}_{3}$. Specific antisera were made $14 \%$ in $\mathrm{Na}_{2} \mathrm{SO}_{4}$ and the precipitated globulin fractions were coupled to bromacetyl cellulose. These immunoadsorbents quantitatively bind their homologous radiolabeled antigens. The binding is inhibited by unlabeled antigen of the same specificity, and the degree of inhibition is quantitatively proportional to the concentration of the unlabeled antigen. IgA and IgM concentrations were measured by radial immunodiffusion (8).

Patient selection. 12 patients with a variety of neoplastic diseases were selected because they had relatively normal serum IgG concentrations (Table I). Ages ranged from 20 to $72 \mathrm{yr}$; four were male, and eight female. 10 additional patients were selected because their serum contained a myeloma protein, thus permitting metabolic studies in eight individuals with a high $G_{1}$ serum concentration, one individual with a high $\mathrm{G}_{2}$ serum concentration, and one with a high $\mathrm{G}_{3}$ serum concentration (Table II). Patients' ages ranged from 33 to $77 \mathrm{yr}$; three were female, seven male. No patients in either group had signs of significant gastrointestinal or renal protein loss.

Turnover study protocol. All subjects were hospitalized at the National Institutes of Health and studies were not performed during periods of acute illness. The serum concentrations of IgG, $G_{1}$, and $G_{3}$ remained constant in both the control and myeloma patients during the study periods, and all patients were therefore assumed to be in a steady state concerning IgG metabolism. 5 drops of Lugol's solution were given three times a day during the entire study to prevent uptake of radioactive iodine by the thyroid.

Subjects received pairs of subclass preparations intravenously, one preparation labeled with ${ }^{125} \mathrm{I}$, the other with ${ }^{131} \mathrm{I}$. The dose of radioactivity ranged from 10 to $25 \mu \mathrm{Ci}$. A $10 \mathrm{~min}$ blood sample was drawn for plasma volume determination. Additional blood samples were collected at $4 \mathrm{hr}$, $8 \mathrm{hr}$, and then daily for 14 days following the administration of labeled protein. Daily $24 \mathrm{hr}$ urine collections were obtained during the study. Serum and urine samples were counted 


\begin{tabular}{|c|c|c|c|c|c|c|c|c|c|c|c|c|}
\hline \multicolumn{2}{|c|}{$\begin{array}{l}\text { IgG subclass } \\
\text { concentration }\end{array}$} & \multirow{2}{*}{$\begin{array}{l}\text { Plasma } \\
\text { volume }\end{array}$} & \multicolumn{2}{|c|}{$\begin{array}{c}\text { Total circulating } \\
\text { pool }\end{array}$} & \multicolumn{2}{|c|}{$\begin{array}{c}\text { Total body } \\
\text { pool }\end{array}$} & \multicolumn{4}{|c|}{ Intravascular } & \multicolumn{2}{|c|}{ Synthetic rate } \\
\hline $\mathrm{G}_{1}$ & $\mathrm{G}_{3}$ & & $\mathrm{G}_{1}$ & $\mathrm{G}_{2}$ & $\mathrm{G}_{1}$ & Gs & $\mathrm{G}_{1}$ & $\mathrm{G}_{2}$ & $\mathrm{G}_{3}$ & $\mathrm{G}_{4}$ & $\mathbf{G}_{\mathbf{1}}$ & $\mathrm{G}_{8}$ \\
\hline \multicolumn{2}{|c|}{$m g / m l$} & $\mathrm{ml} / \mathrm{kg}$ & \multicolumn{2}{|c|}{$m g / k g$} & \multicolumn{2}{|c|}{$m g / k g$} & & \multicolumn{2}{|c|}{$\%$} & & \multicolumn{2}{|c|}{$m g / k g / d a y$} \\
\hline & 0.32 & 45 & & 14.4 & & 25.3 & & 46 & 57 & & & 2.5 \\
\hline & 0.71 & 34 & & 24.2 & & 33.6 & & 62 & 72 & & & 4.0 \\
\hline & 0.35 & 46 & & 16.1 & & 23.3 & & 53 & 69 & & & 2.6 \\
\hline & 0.76 & 37 & & 28.1 & , & 44.7 & & 52 & 63 & & & 4.6 \\
\hline & 0.38 & 47 & & 17.9 & & 32.5 & & & 55 & & & 3.1 \\
\hline & 0.46 & 42 & & 19.3 & & 27.9 & & & 69 & & & 3.4 \\
\hline 8.5 & & 42 & 357 & & 744 & & 48 & & & 52 & 29.3 & \\
\hline 4.1 & & 44 & 180 & & 340 & & 53 & & & 56 & 8.1 & \\
\hline 4.5 & & 41 & 184 & & 355 & & 52 & & & 52 & 16.9 & \\
\hline 6.0 & & 36 & 216 & & 460 & & 47 & & & & 13.0 & \\
\hline 9.0 & & 46 & 414 & & 882 & & 47 & & & 48 & 41.4 & \\
\hline 9.1 & & 48 & 437 & & 753 & & 58 & & & 64 & 43.7 & \\
\hline 6.9 & 0.50 & 42 & 298 & 20.0 & 589 & 31.2 & 51 & 53 & 64 & 54 & 25.4 & 3.4 \\
\hline \pm 2.1 & \pm 0.17 & \pm 4 & \pm 108 & \pm 4.8 & \pm 212 & \pm 7.0 & \pm 4 & \pm 6 & \pm 6 & \pm 5 & \pm 13.7 & \pm 0.7 \\
\hline
\end{tabular}

with appropriate standards in an automatic gamma ray welltype scintillation counter with a thallium-activated sodium iodide crystal. A pulse height analyzer allowed differentiation of the two isotopes in the samples.

In vivo labeled $G_{s}-m y e l o m a$ protein turnover study. A single intravenous dose of $100 \mu \mathrm{Ci}$ of guanidoarginine ${ }^{14} \mathrm{C}$ was given to patient $G$. B. who had a serum $G_{3}$-myeloma protein (Table II). Plasma samples were obtained daily. The myeloma protein was isolated from each plasma sample, and $5 \mathrm{mg}$ of the protein were completely precipitated with $10 \%$ trichloracetic acid. Precipitates were dissolved in 0.5 $\mathrm{ml}$ of NCS reagent (Nuclear-Chicago), ${ }^{2} 10 \mathrm{ml}$ of a mixture of Liquifluor (New England Nuclear) ${ }^{3}$ and toluene was added, and radioactivity was determined in a liquid scintillation counter (Packard Tri-Carb Model 4322). The rate of decrease of specific activity of the $\mathrm{G}_{\mathbf{8}}$-myeloma protein reflects the biologic survival of this protein.

Calculation of the metabolic data. Whole body radioactivity was calculated by cumulative subtraction of the radioactivity appearing in the urine. Graphs of change in plasma and whole body radioactivity were constructed on semilogarithmic paper. The biologic half-life $\left(t_{3}\right)$ of each labeled protein was determined graphically. The total circulating and total body protein pools, the fraction of the body protein pool remaining intravascular, the fraction of the intravascular pool catabolized each day (fractional catabolic rate or FCR), and the synthetic rate (turnover rate) were determined by a modification of the method of Matthews (9).

\section{RESULTS}

Subjects with normal IgG levels. Turnover data from studies in subjects with normal serum IgG concentrations are summarized in Table I. Five subjects received ${ }^{131} \mathrm{I}_{-} \mathrm{G}_{4} \kappa$ and ${ }^{125} \mathrm{I}-\mathrm{G}_{\mathrm{I}} \lambda$ simultaneously, one was injected

\footnotetext{
${ }^{2}$ Nuclear-Chicago Corporation, Des Plaines, Ill.

${ }^{3}$ New England Nuclear Corp., Boston, Mass.

" Packard Instrument Co., Downers Grove, Ill.
}

only with ${ }^{125} \mathrm{I}-\mathrm{G}_{1} \lambda$, four received ${ }^{125} \mathrm{I}-\mathrm{G}_{2} \kappa$ and ${ }^{131} \mathrm{I}-\mathrm{G}_{3} \kappa$ simultaneously, and two received only ${ }^{125} \mathrm{I}-\mathrm{G}_{3} \lambda$.

The biologic half-life of the $G_{2}, G_{2}$, and $G_{4}$ proteins showed considerable variation when studied in different individuals. Average values, however, were similar for all three subclasses (Table I). The observed half-times of survival of 20.2 to 21.2 days are similar to those previously reported for whole IgG (23 \pm 4 days) (10). The survival of both $\mathrm{G}_{3}$ proteins, however, was short, with a mean of $7.1 \pm 0.7$ days (Table I).

The fraction of the intravascular pool catabolized per day (FCR) of the four subclasses is shown in Table $I$. Rates for $G_{1}, G_{2}$, and $G_{4}$ were between 0.05 and 0.10 of the intravascular pool per day, values which are similar to the FCR of whole IgG $(0.067 \pm 0.015)$. The fractional catabolic rates of the $\mathrm{Gs}$ proteins were considerably higher and ranged from 0.159 to 0.175 of the intravascular pool per day.

It was necessary to determine whether the short survival and high fractional catabolic rate of Gs was due to damage of this labile molecule during isolation and radiolabeling, or whether this rate was indeed a metabolic property of native Gs. To accomplish this, an in vivo labeling procedure was utilized so that it was not necessary to isolate and label the Gs-myeloma protein prior to its metabolism in vivo. Patient G.B., whose serum contained a Gs-myeloma protein (Table II), was given a single intravenous dose of $100 \mu \mathrm{Ci}$ of guanidoarginine- ${ }^{14} \mathrm{C}$. On each of the 10 following days (except day 9) plasma samples were obtained, myeloma protein was isolated, and specific activity determined (see Methods). ${ }^{14} \mathrm{C}$ was rapidly incorporated into the myeloma protein, such that the specific activity was high $24 \mathrm{hr}$ 
TABLE II

Clinical and Turnover

\begin{tabular}{|c|c|c|c|c|c|c|c|c|c|c|c|c|c|}
\hline \multirow[b]{2}{*}{ Initials } & \multirow[b]{2}{*}{ Sex } & \multirow[b]{2}{*}{ Age } & \multirow[b]{2}{*}{ Weight } & \multirow{2}{*}{$\begin{array}{l}\text { Serum- } \\
\text { IgG }\end{array}$} & \multirow{2}{*}{$\frac{\text { Myeloma protein }}{\text { (subclass, type) }}$} & \multicolumn{4}{|c|}{ Survival $t_{t}$} & \multicolumn{4}{|c|}{$\begin{array}{l}\text { Fraction of intravascular pool } \\
\text { catabolized } / \text { day }\end{array}$} \\
\hline & & & & & & $\mathrm{G}_{1}$ & $\mathrm{G}_{2}$ & $\mathrm{G}_{3}$ & $\mathrm{G}_{4}$ & $\mathrm{G}_{1}$ & $\mathrm{G}_{2}$ & $\mathrm{G}_{3}$ & $\mathrm{G}_{4}$ \\
\hline & & $y r$ & kg & $m g / m l$ & \multicolumn{9}{|c|}{ days } \\
\hline P. E. & $\mathbf{M}$ & 50 & 67.3 & 14 & $\operatorname{IgG}_{1} \lambda$ & & 11.0 & 4.0 & & & 0.15 & 0.26 & \\
\hline G. B. & $\mathrm{F}$ & 47 & 51.0 & 33 & $\operatorname{IgG}_{3 K}$ & & 8.0 & 3.5 & & & 0.15 & 0.38 & \\
\hline N. A. S. & $\mathrm{M}$ & 51 & 73.8 & 49 & $\operatorname{IgG}_{2} \kappa$ & 7.0 & 10.6 & 3.0 & 10.5 & 0.14 & 0.11 & 0.27 & 0.11 \\
\hline D. P. & $\mathrm{M}$ & 33 & 61.0 & 35 & $\operatorname{IgG}_{1} \kappa$ & 10.0 & 11.0 & 3.5 & 12.0 & 0.12 & 0.12 & 0.29 & 0.11 \\
\hline D. S. & $\mathrm{F}$ & 77 & 38.5 & 17 & $\operatorname{IgG}_{1 \kappa}$ & 13.5 & & & 14.0 & 0.11 & & & 0.11 \\
\hline L. C. D. & $\mathbf{M}$ & 44 & 77.6 & 62 & $\operatorname{IgG}_{1} \lambda$ & 5.4 & & & 6.5 & 0.19 & & & 0.15 \\
\hline C. W. & $\mathbf{M}$ & 46 & 95.5 & 27 & $\operatorname{IgG}_{1 K}$ & 10.5 & & & 13.0 & 0.13 & & & 0.10 \\
\hline M. J. K. & $\mathrm{F}$ & 46 & 59.7 & 32 & $\operatorname{IgG}_{1 \kappa}$ & 16.5 & & & 16.0 & 0.08 & & & 0.08 \\
\hline J. D. W. & $\mathrm{M}$ & 76 & 54.8 & 45 & $\operatorname{IgG}_{1} \kappa$ & 18.0 & & & 18.5 & 0.07 & & & 0.07 \\
\hline D. D. & $\mathbf{M}$ & 38 & 80.9 & 25 & $\operatorname{IgG}_{1} \kappa$ & 10.5 & & & 11.0 & 0.15 & & & 0.14 \\
\hline \multicolumn{2}{|c|}{ Mean $\pm 1 \mathrm{SD}$} & & & & & 11.4 & 10.2 & 3.5 & 12.7 & 0.12 & 0.13 & 0.30 & 0.11 \\
\hline
\end{tabular}

after administration and then progressively decreased with time. A semilogarithmic plot of the decrease of ${ }^{14} \mathrm{C}$ specific activity of the Gs-myeloma protein yields a straight line, with slope indicating a half-life of 3.5 days. This is similar to the half-life obtained with the patients exogenously labeled ${ }^{181} \mathrm{I}_{-} \mathrm{G}_{3}$ (Fig. 1). These data show that the metabolic behavior of in vivo and in vitro labeled $\mathrm{G}_{3}$ proteins are the same and indicate that the short survival and high FCR of $\mathrm{G}_{3}$ are properties of native $\mathrm{G}_{3}$ molecules.

In order to calculate the pool sizes and synthetic rates of $G_{1}$ and $G_{3}$, it was necessary to determine the serum concentration of these subclasses in all patients. For comparative purposes, the $\mathrm{IgG}, \mathrm{G}_{1}$, and $\mathrm{G}_{3}$ serum concentrations were also determined in the sera of 20 normal blood donors. The average normal values $\pm 1 \mathrm{sD}$ were: $\mathrm{IgG}, 10.0 \pm 2.3 \mathrm{mg} / \mathrm{ml} ; \mathrm{G}_{1}, 6.8 \pm 2.6 \mathrm{mg} / \mathrm{ml}$; and $\mathrm{G}_{3}, 0.7$ $\pm 0.3 \mathrm{mg} / \mathrm{ml}$. Levels in the patients selected for normal IgG serum concentration generally fell within 1 SD of the control group (Table I). Using these serum concentrations, total circulating, and total body pools for $\mathrm{IgG}, \mathrm{G}_{1}$, and $\mathrm{G}_{3}$ were calculated (Table $\mathrm{I}$ ). The distribution of $\mathrm{G}_{3}$ into the intravascular compartment was relatively high, and amounted to an average of $64 \%$ of the total body pool. By comparison, only 51, 53, and $54 \%$ of the total body pools of $\mathrm{G}_{1}, \mathrm{G}_{2}$, and $\mathrm{G}_{4}$ were located in the intravascular compartments.

Synthetic rates for $G_{1}$ and $G_{3}$ in the patient group with normal IgG concentrations were calculated and compared with the synthetic rate of $\mathrm{IgG}$, which has previously been reported as $34 \pm 11 \mathrm{mg} / \mathrm{kg}$ per day (10). Although there was a considerable range in the individual values for $G_{1}$ synthesis, the average rate was
$25 \pm 14 \mathrm{mg} / \mathrm{kg}$ per day, which is $70 \%$ that of $\mathrm{IgG}$. By contrast, the average $\mathrm{G}_{3}$ synthetic rate was $3.4 \pm 0.7$ $\mathrm{mg} / \mathrm{kg}$ per day, or about $10 \%$ of the synthetic rate of IgG.

Myeloma patients. Table II summarizes the turnover data of the myeloma patients. As shown in previous studies $(10,11)$, myeloma patients have a higher plasma volume than normal individuals. In the present study, the plasma volume of the myeloma patients averaged $53 \pm 10$ $\mathrm{ml} / \mathrm{kg}$, compared to $42 \pm 4 \mathrm{ml} / \mathrm{kg}$ in the control patients. The intravascular compartment contained 59,56 , and $59 \%$ of the total body pools of $\mathrm{G}_{1}, \mathrm{G}_{2}$, and $\mathrm{G}_{4}$, and $77 \%$ of the total body pool of $\mathrm{G}_{3}$.

The survival of each of the subclasses was significantly shorter in myeloma patients than in controls, and the FCR was approximately twice that of controls. A possible explanation for the shortened survival relates to IgG concentration, in that it has previously been noted that patients with elevated IgG serum concentrations have shortened survival of IgG $(10,12-15)$; that is, there appears to be an inverse relationship between serum IgG concentration and IgG survival. In the present study, survival times generally were shortest in recipients with the highest IgG levels. Studies in patients with elevated serum levels of $G_{1}, G_{2}$, or $G_{3}$ showed that survival of all four subclasses were decreased and catabolic rates increased (Figs. 2, 3). This relationship between serum concentration and catabolism of $\mathrm{IgG}$ is, therefore, applicable to elevation of $\mathrm{G}_{1}$, $\mathrm{G}_{2}$, or $\mathrm{G}_{3}$ and is presumably valid also for elevation of $\mathrm{G}_{4}$.

There were, however, some exceptions to this relationship. P. E., who had a low serum concentration of 
Data of Myeloma Patients

\begin{tabular}{|c|c|c|c|c|c|c|c|c|c|c|c|c|c|c|c|c|c|c|}
\hline \multicolumn{5}{|c|}{ Ig Concentration } & \multirow{3}{*}{$\begin{array}{l}\text { Plasma } \\
\text { volume }\end{array}$} & \multirow{2}{*}{\multicolumn{3}{|c|}{ Total circulating pool }} & \multirow{2}{*}{\multicolumn{3}{|c|}{ Total body pool }} & \multirow{2}{*}{\multicolumn{4}{|c|}{ Intravascular }} & \multirow{2}{*}{\multicolumn{3}{|c|}{ Synthetic rate }} \\
\hline \multicolumn{3}{|c|}{ IgG } & \multirow[b]{2}{*}{ IgA } & \multirow[b]{2}{*}{$\mathrm{IgM}$} & & & & & & & & & & & & & & \\
\hline $\mathbf{G}_{1 \kappa}$ & $\mathrm{G}_{1} \lambda$ & $\mathrm{G}_{3}$ & & & & $\mathrm{G}_{1 \kappa}$ & $\mathrm{G}_{1} \lambda$ & Gs & $\mathrm{G}_{1 \kappa}$ & $\mathrm{G}_{1} \lambda$ & $\mathrm{G}_{3}$ & $\mathrm{G}_{1}$ & $\mathrm{G}_{2}$ & $\mathrm{G}_{\mathbf{3}}$ & G4 & Gix & $\mathrm{G}_{1} \lambda$ & Gs \\
\hline & & $m g / m l$ & & & $\mathrm{ml} / \mathrm{kg}$ & \multicolumn{3}{|c|}{$m g / k g$} & \multicolumn{3}{|c|}{$\mathrm{mg} / \mathrm{kg}$} & \multicolumn{4}{|c|}{$\%$} & \multicolumn{3}{|c|}{$m g / k g / d a y$} \\
\hline 5.9 & 5.0 & 0.92 & 1.10 & 1.20 & 46 & 271 & 230 & 42 & & & 54 & & 48 & 78 & & & & 11 \\
\hline 1.7 & 0.9 & 30.0 & 0.43 & 0.32 & 59 & 100 & 53 & 1770 & & & 3052 & & 62 & 58 & & & & 673 \\
\hline 0.7 & 0.3 & 0.15 & 0.20 & 0.18 & 52 & 36 & 16 & 8 & 50 & 22 & 9 & 72 & 55 & 86 & 66 & 5 & 2 & 2 \\
\hline 33.0 & 0.6 & 0.22 & 0.26 & 0.32 & 62 & 2046 & 37 & 14 & 3197 & 58 & 18 & 64 & 59 & 77 & 61 & 246 & 4 & 4 \\
\hline 15.0 & 0.7 & 0.20 & 0.16 & 0.32 & 68 & 1020 & 48 & 14 & 2000 & 94 & & 51 & & & 51 & 112 & 5 & \\
\hline 0.7 & 60.0 & 0.035 & 0.13 & 0.24 & 52 & 36 & 3120 & 2 & 65 & $4588^{\circ}$ & & 68 & & & 70 & 7 & 593 & \\
\hline 26.0 & 0.2 & 0.053 & 0.11 & 0.05 & 52 & 135 & 10 & 3 & 2458 & 19 & & 55 & & & 52 & 175 & 1 & \\
\hline 30.0 & 1.0 & 0.26 & 0.36 & 1.90 & 51 & 1530 & 51 & 13 & 2942 & 98 & & 56 & & & 57 & 122 & 4 & \\
\hline 43.0 & 1.0 & 0.22 & 0.22 & 0.42 & 56 & 2408 & 56 & 12 & 4152 & 97 & & 58 & & & 60 & 168 & 4 & \\
\hline \multirow[t]{2}{*}{22.0} & 1.2 & 1.10 & 0.50 & 0.68 & 29 & 638 & 35 & 32 & 1225 & 67 & & 52 & & & 53 & 96 & 5 & \\
\hline & & & 0.35 & 0.56 & $53 \pm 10$ & & & & & & & 59 & 56 & 77 & 59 & & & \\
\hline
\end{tabular}

Gi myeloma protein (MP), had remarkably short survival times, whereas J. D. W. and, to a lesser extent, M. J. K. showed almost normal biologic half-lives of G and $G_{*}$ in spite of clearly elevated serum IgG levels.

The synthetic rates of myeloma proteins in myeloma patients are high, as expected. In two patients, L. C. D. and G. B., synthetic rates of 593 and $673 \mathrm{mg} / \mathrm{kg}$ per day were observed, indicating a daily synthesis of 46 and $34 \mathrm{~g}$ of MP respectively in these patients.

The serum concentration of "nonmyeloma" IgG (e.g.

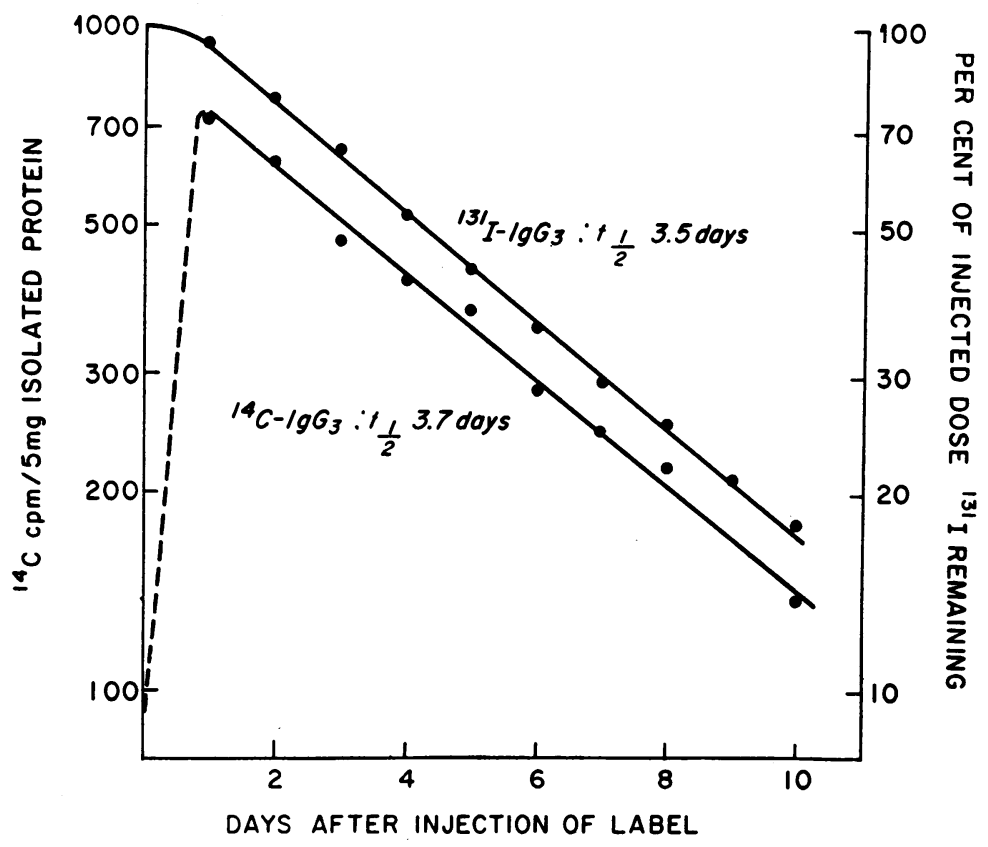

FIGURE 1 Survival of $\operatorname{IgG}_{3}$ in a patient with elevated serum concentration of $\mathrm{IgG}_{3}$. A turnover study of iodinated $\mathrm{IgG}_{3}$ was performed in the usual manner. Upper curve shows residual whole body activity. In a separate study, the patient was given guanidoarginine $-{ }^{14} \mathrm{C}$ and the myeloma protein was isolated from her serum on each of the next 10 days. The decrease of serum myeloma protein specific activity is shown in the lower curve. 
IgG of the subclasses other than the myeloma proten, or of the same subclass but of the other light chain type) is usually markedly decreased (Table II). For example, the average $\mathrm{G}_{1} \lambda$ serum concentration in eight patients with myeloma proteins of non- $\mathrm{G}_{1} \lambda$ type was $0.7 \mathrm{mg} / \mathrm{ml}$, as compared to an average of $2.8 \mathrm{mg} / \mathrm{ml}$ in nonmyeloma patients. The rates of synthesis of nonmyeloma IgG are about 1 SD below the average synthetic rates of control patients. The low levels of "nonmyeloma" IgG are, therefore, due not only to the increased fractional catabolic rate (Tables I and II) but also to reduced synthesis (Fig. 4).

\section{DISCUSSION}

The biologic half-lives and fractional catabolic rates of the $G_{1}, G_{2}$, and $G_{4}$ subclasses were similar to one another and to the values previously reported for IgG. It is not surprising that the survival of $G_{1}$ and $G_{2}$ should be similar to that of $\mathrm{IgG}$, since $\mathrm{G}_{1}$ and $\mathrm{G}_{2}$ constitute approximately $90 \%$ of the $\operatorname{IgG}$ used in previous studies. In the only other reported turnover study of the IgG subclasses, considerably shorter survival times were reported for $G_{1}, G_{2}$, and $G_{4}(11.6,12.4$, and 11.3 days respectively) (4). This discrepancy may be due to differences in radiolabeling techniques, since these investigators used the chloramine- $\mathrm{T}$ method, and proteins

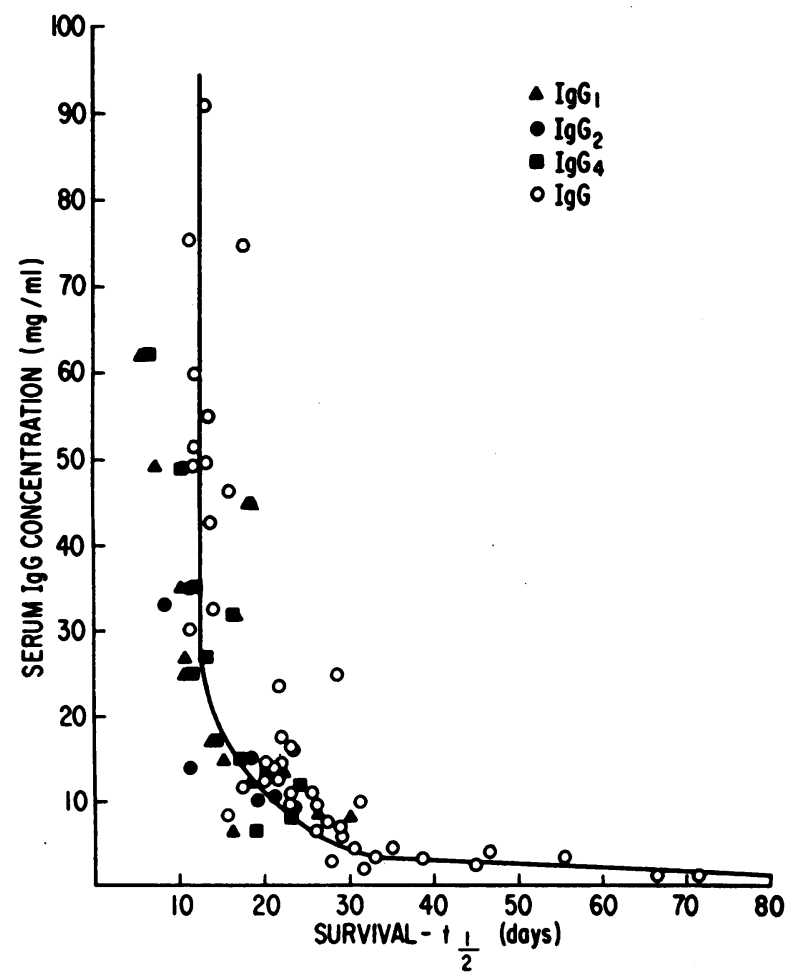

FIGURE 2 The relationship between serum IgG concentration and survival $\left(t_{\frac{1}{2}}\right)$ of $\operatorname{IgG}, \operatorname{IgG}_{1}, \operatorname{IgG}_{2}$, and $\operatorname{IgG}_{4}$ proteins.

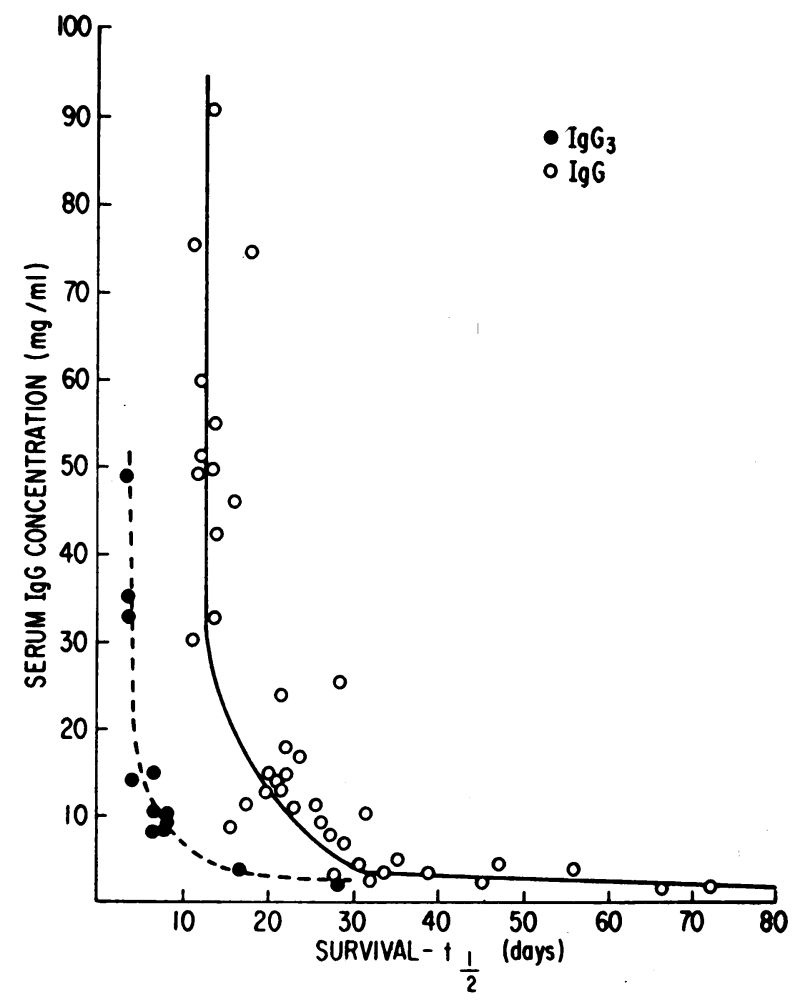

Figure 3 The relationship between serum IgG concentration and survival $\left(t_{\frac{1}{3}}\right)$ of $\operatorname{IgG}$ and $\operatorname{IgG}_{3}$ proteins.

labeled by that procedure may have shortened survival times.

$\mathrm{IgG}_{3}$ was catabolized two to three times more rapidly than the other subclasses. Gs, however, is known to be a labile molecule (16). It may be fragmented upon serum storage and is very rapidly destroyed by proteolytic enzymes. It was necessary, therefore, to prove that the apparent short survival was not due to molecular degradation occurring during the isolation and radiolabeling of the myeloma protein. This possibility was tested by biosynthetically labeling a $\mathrm{G}_{3}$-myeloma protein, thus avoiding the need to isolate and radiolabel the protein before injecting it for turnover study. In this procedure, isolation of the $\mathrm{G}_{3}$ protein occurs after metabolism has taken place and any damage occurring during isolation does not affect the results. A patient

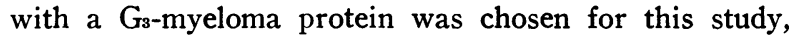
since the low level of $\mathrm{G}_{3}$ in normal serum makes it very difficult to isolate normal serum $G_{s}$ free of other serum proteins. Results of this study clearly show that the in vivo and in vitro labeled $\mathrm{G}_{3}$ are metabolized similarly (Fig. 1) and indicate that the short survival and high catabolic rate of $\mathrm{G}_{3}$ is a property of the native molecule. Since IgG subclasses differ from one another in the primary amino acid sequence of their $\mathrm{Fc}$-fragments 
$(17,18)$, and since it has been shown that survival of the IgG Fc-fragment is similar to that of the whole molecule, while survival of Fab-fragment is very short (2), it can be concluded that the unique metabolic properties of $\mathrm{IgG}_{s}$ are determined by its $\mathrm{Fc}$-fragment.

The normal serum concentration of $\mathrm{G}_{s}$ is low, averaging in this study about $0.7 \mathrm{mg} / \mathrm{ml}$, and $\mathrm{G}_{3}$ accounts for only $7 \%$ of the total serum IgG. Calculated synthetic rates are also low, and the low serum $G_{3}$ concentration apparently results from the combination of a low synthetic rate and a high fractional catabolic rate. The synthetic rate of $G_{1}$ is about seven times that of $G_{8}$. The reason for this difference appears to be that in each individual, many more cells secrete $G_{1}$ than secrete Gs protein. This conclusion is supported by fluorescent antibody studies of human spleen cells which show that of the cells containing IgG, only about $10 \%$ contain Gs (19). It was not possible to calculate synthetic rates of $G_{2}$ and $G_{4}$ because methods for determining serum concentrations of these two subclasses were not available.

In IgG-myeloma patients the concentration of nonmyeloma IgG is usually decreased $(20,21)$. The present data indicate that this low level of nonmyeloma IgG is due to a combination of reduced synthesis and increased fractional catabolic rate. IgM and IgA serum concentrations are reduced in most cases of IgG-myeloma (20, 21). The survivals of $\operatorname{IgA}$ and IgM are normal in

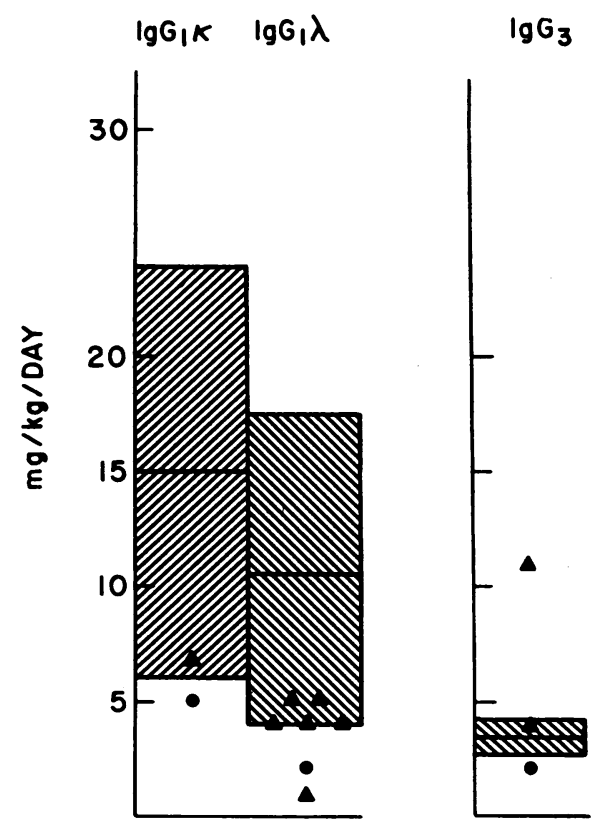

Figure 4 Synthesis of $\operatorname{IgG}_{1} \kappa$, and $\operatorname{IgG}_{1} \lambda$ and $\operatorname{IgG}_{3}$ in patients with $\mathrm{G}_{1}$ myeloma protein ( $\left.\boldsymbol{\Delta}\right)$ or $\mathrm{G}_{2}$ myeloma protein (•). Synthetic rates of "nonmyeloma" $\mathrm{G}_{1}$ in myeloma patients are generally low when compared with those of patients with normal IgG serum concentrations (cross hatched areas). myeloma patients, while synthetic rates are profoundly reduced, to less than $15 \%$ of normal for IgM (22). The low levels of $\operatorname{IgM}$ and $\operatorname{IgA}$ are, therefore, caused solely by decreased synthesis.

The serum concentration of IgG is an important factor in the control of human IgG catabolic rates. High serum levels of IgG are associated with high fractional catabolic rates (short IgG survivals), while low levels of IgG, as in humans with hypogammaglobulinemia, are associated with low catabolic rates and prolonged survival. The relationship between concentration and catabolism is specific for IgG molecules. The survival of IgG is not affected by the concentration of other serum proteins, including the other immunoglobulins $(15,23)$. The concentration-catabolism relationship must reflect the nature of the mechanism whereby $\operatorname{IgG}$ molecules are catabolized. It was of interest, therefore, to determine whether all subclasses participated in this phenomenon, especially since the catabolic rate of $\mathrm{G}_{3}$ differs so markedly from that of the others. Representative proteins of each of the four subclasses were studied in patients with a range of serum levels of IgG. In general, catabolic rates were proportional to serum $\mathrm{IgG}$ concentration. Patients with $\mathrm{G}_{1}, \mathrm{G}_{2}$, or $\mathrm{G}_{3}$ myeloma proteins were included in the study and it can be concluded, at least for these three subclasses, that an elevation of one subclass shortens the survival of all subclasses. Patients with elevated serum $\mathrm{G}_{4}$ concentrations were not available. The concentration-catabolism relationships for isolated $\mathrm{G}_{1}, \mathrm{G}_{2}$, and $\mathrm{G}_{4}$ proteins were very similar to that of IgG over the range investigated (Fig. 2). Gr proteins showed a similar relationship, although the curve is displaced from that produced by IgG (Fig. $3)$. Two $G_{3}$ metabolic studies were performed in patients with hypogammaglobulinemia. The survival of $\mathrm{G}_{3}$ in these patients was two to three times longer than in recipients with normal IgG concentrations, and seven times longer than in a patient with multiple myeloma and an IgG serum concentration of $30 \mathrm{mg} / \mathrm{ml}$ (Fig. 3).

Murine serum also contains definable IgG subclasses whose metabolic properties have been studied. The results are quite parallel to those found in man. One of the murine subclasses, $\gamma_{2 b}(\gamma \mathrm{GH})$ has a shorter survival and higher fractional catabolic rate than the other subclasses (24). In mouse, as in man, a concentrationcatabolism relationship has been observed; mice with high serum levels of IgG have high fractional catabolic rates, while those with low serum levels have low catabolic rates and long survival $(23,25)$.

The mechanism by which IgG is metabolically degraded is unknown. Brambell, Hemmings, and Morris (26) have proposed a hypothetical mechanism for catabolism which postulates a saturable protection system for IgG. IgG molecules are presumed to pass randomly 
from the intravascular compartment to a closed compartment, such as a pinocytotic vacuole. Within the vacuole are a limited number of IgG specific receptor sites, to which a fraction of the trapped IgG molecules become attached. Proteolytic enzymes are released into the vacuole. Those molecules attached to receptor sites are protected, and subsequently released into the circulation, while unattached molecules are degraded.

The concentration-catabolism relationship demonstrated for a majority of the patients in the present study is consistent with this hypothesis and expands it by indicating that there are no subclass specific protective receptor sites. All four subclasses compete for the same receptors. A myeloma protein of any of the subclasses therefore would, by the overwhelming number of its molecules, occupy almost all the protective sites, leaving the molecules of the other subclasses exposed to catabolism at a high rate. The hypothesis must be modified, however, to account for the facts that $\mathrm{G}_{3}$ participates in the concentration-catabolism relationship, but has a much higher catabolic rate. This indicates that although $\mathrm{G}_{3}$ proteins share metabolic pathways with the other subclasses, they also are acted upon by other catabolic mechanisms. The location of catabolic sites and the details of both the catabolic mechanisms proposed by Brambell and the additional ones suggested by these studies are unknown at this time.

\section{ACKNOWLEDGMENTS}

Dr. Morell is supported by Grant No. 5324.3 of the Swiss National Foundation for Scientific Research.

\section{REFERENCES}

1. Yount, W. J., M. M. Dorner, H. G. Kunkel, and E. A. Kabat. 1968. Studies on human antibodies. IV. Selective variations in subgroup composition and genetic markers. J. Exp. Med. 127: 633 .

2. Spiegelberg, H. L., and W. O. Weigle. 1965. The catabolism of homologous and heterologous $7 \mathrm{~s}$ gamma globulin fragments. J. Exp. Med. 121: 323.

3. Wochner, R. D., W. Strober, and T. A. Waldmann. 1967. The role of the kidney in the catabolism of Bence Jones proteins and immunoglobulin fragments. $J$. Exp. Med. 126: 207.

4. Spiegelberg, H. L., B. G. Fishkin, and H. M. Grey. 1968. Catabolism of human $\gamma \mathrm{G}$-immunoglobulins of different heavy chain subclasses. I. Catabolism of $\gamma \mathrm{G}$-myeloma proteins in man. J. Clin. Invest. 47: 2323.

5. Spiegelberg, H. L., and H. M. Grey. 1968. Catabolism of human $\gamma \mathrm{G}$-immunoglobulins of different heavy chain subclasses. II. Catabolism of $\gamma \mathrm{G}$-myeloma proteins in heterologous species. J. Immunol. 101: 711.

6. McFarlane, A. S. 1958. Effective trace-labelling of proteins with iodine. Nature (London). 182: 53.

7. Mann, D., H. Granger, and J. L. Fahey. 1969. Use of insoluble antibody for quantitative determination of small amounts of immunoglobulin. J. Immunol. 102: 618.
8. Fahey, J. L., and E. M. McKelvey. 1965. Quantitative determination of serum immunoglobulins in antibody-agar plates. J. Immunol. 94 : 84.

9. Matthews, C. M. E. 1957. The theory of tracer experiments with ${ }^{131} \mathrm{I}$-labelled plasma proteins. Phys. Med. Biol. $2: 36$.

10. Solomon, A., T. A. Waldmann, and J. L. Fahey. 1963. Metabolism of normal $6.6 \mathrm{~S} \gamma$-globulin in normal subjects and in patients with macroglobulinemia and multiple myeloma. J. Lab. Clin. Med. 62: 1.

11. Andersen, S. B. 1964. Metabolism of Human Gamma Globulin ( $\gamma$ ss-Globulin). Blackwell Scientific Publications, Ltd., Oxford.

12. Lippincott, S. W., S. Korman, C. Fong, E. Stickley, W. Wolins, and W. L. Hughes. 1960. Turnover of labelled normal gamma globulin in multiple myeloma. J. Clin. Invest. 39: 565.

13. Cohen, S., I. A. McGregor, and S. Carrington. 1961. Gamma-globulin and acquired immunity to human malaria. Nature (London). 192: 733.

14. Birke, G., S. O. Liljedah1, B. Olhagen, L. O. Plantin, and S. Ahlinder. 1963. Catabolism and distribution of gammaglobulin. A preliminary study with ${ }^{131}$ I-labelled gammaglobulin. Acta Med. Scand. 173: 589.

15. Waldmann, T. A., and W. Strober. 1969. Metabolism of imunoglobulins. Progr. Allergy. 1.3: 1.

16. Yount, W. J., H. G. Kunkel, and S. D. Litwin. 1967. Studies of the Vi $(\gamma 2 \mathrm{c})$ subgroup of $\gamma$-globulin. A relationship between concentration and genetic type among normal individuals. J. Exp. Med. 125: 177.

17. Prahl, J. W. 1967. The C-terminal sequences of the heavy chains of human immunoglobulin $\mathrm{G}$ myeloma proteins of different isotypes and allotypes. Biochem. J. 105 : 1019.

18. Frangione, B., C. Milstein, and J. R. L. Pink. 1969. Structural studies of immunoglobulin G. Nature (London). 221: 145 .

19. Bernier, G. M., R. E. Ballieux, K. T. Tominaga, and F. W. Putnam. 1967. Heavy chain subclasses of human $\gamma$ G-globulin. Serum distribution and cellular localization. J. Exp. Med. 125 : 303.

20. McKelvey, E. M., and J. L. Fahey. 1965. Immunoglobulin changes in disease: quantitation on the basis of heavy polypeptide chains, $\operatorname{IgG}(\gamma \mathrm{G}), \operatorname{Ig} \mathrm{A}(\gamma \mathrm{A})$, and $\operatorname{IgM}(\gamma \mathrm{M})$, and of light polypeptide chains, type $\mathrm{K}$ (I) and type L (II). J. Clin. Invest. 44: 1778.

21. Fahey, J. L., R. Scoggins, J. P. Utz, and C. F. Szwed. 1963. Infection, antibody response and gamma globulin components in multiple myeloma and macroglobulinemia. Amer. J. Med. 35 : 698.

22. Barth. W. F., R. D. Wochner, T. A. Waldmann, and J. L. Fahey. 1964. Metabolism of human gamma macroglobulins. J. Clin. Invest. 43 : 1036.

23. Fahey, J. L., and A. G. Robinson. 1963. Factors controlling serum $\gamma$-globulin concentration. J. Exp. Med. $118: 845$.

24. Fahey, J. L., and S. Sell. 1965. The immunoglobulins of mice. V. The metabolic (catabolic) properties of five immunoglobulin classes. J. Exp. Med. 122: 41.

25. Sell, S., and J. L. Fahey. 1964. Relationship between $\gamma$-globulin metabolism and low serum $\gamma$-globulin in germfree mice. J. Immunol. $93: 81$.

26. Brambell, F. W. R., W. A. Hemmings, and I. G. Morris. 1964. A theoretical model of $\gamma$-globulin catabolism. Nature (London). 203: 1352. 